\title{
Political Economy and Urban Poverty in the Developing Countries: Lessons Learned from Sudan and Malaysia
}

\author{
Yasin Abdalla Eltayeb Elhadary (Main author) \\ Faculty of Geography, University of Khartoum \\ Post doctoral of Universiti sains Malaysia, 11800-Penang, Malaysia \\ Tel: 60-125-996-924 E-mail: yasin@usm.my
}

Narimah Samat

School of Humanities-Geography Section, Universiti sains Malaysia, 11800-Penang, Malaysia

Tel: 60-125-018-834Ｅ-mail: narimah@usm.my

Received: September 21, $2011 \quad$ Accepted: October 8, $2011 \quad$ Published: March 1, 2012

doi:10.5539/jgg.v4n1p212 URL: http://dx.doi.org/10.5539/jgg.v4n1p212

\begin{abstract}
The number of people living in towns has increased very rapidly particularly in the developing countries due to massive rural urban migration as well as natural population growth. Significant increase of urban population in a short span of time has created various problems including inequality in provision of social services, decline in farming activities, and increase number of urban poor. In countries like Sudan and Malaysia, rapid urbanization and high cost of living has pushed urban dwellers particularly the vulnerable group into deep poverty. Despite this fact, less attention is paid to the urban poor and most of international and national aid agencies are focusing on rural poverty. This paper, therefore, aims to contribute to the discussion of the issue of urban poverty in the developing countries, taking Sudan and Malaysia as examples. The objective is to highlight the current situation of urban poverty with particular emphasis on its pattern, causes, and the policies adopted by both countries to eradicate poverty. The use of the political economy approach has come out with the suggestion that urban poor in developing countries has been impoverished by ineffective economic policies developed abroad as well as at national level. Despite the effort made to eradicate poverty, there is an urgent need to address issues like food insecurity, socio-economic inequality and regional disparities.
\end{abstract}

Keywords: Malaysia, Sudan, Urbanization, Urban poverty, Structural adjustment program

\section{Introduction}

Urban population has increased very rapidly and is expected to continue for the coming decades especially in the developing countries. In 1950, for example, urban population in developing nations was less than 300 million and it increased to 1.1 billion in 1985. Furthermore, it was projected that more than 4 billion people will be living in the major urban conurbations of developing nations by the year 2025 (UNCHS, 1996). Between 1990 and 2000, the annual population growth and built areas were only $0.6 \%$ and $2.9 \%$ respectively for the developed nations. However, in the developing countries the annual population growth and built-areas were $1.8 \%$ and $3.6 \%$ respectively (World Bank, 2005). In this high speed rate of growth, managing urbanization has become a major challenge among planners and decision makers in both developed and developing nations (Devas and Rakodi, 1993; Choguill, 1994).

High speed of urban expansion caused various problems for local government especially in fulfilling the provision of services and infrastructures, creating job opportunities and providing houses for urban dwellers. This has been aggravated by the fact that most of the developing countries have insufficient resources and personnel to cater for such development (Samat, 2002). This implies that the ability of urbanization to absorb the influx of migrant into urban labor market needs to be revised. In Dhaka, the capital of Bangladesh, for example, mass migration to the city from countryside and high birth rate bears the distinction of being the fastest growing in the world creates serious environmental and social problem (German and Pyne, 2010). In that country, the 
average density of the built-up area is 8,000 persons per square kilometer and it is anticipated that the density will increase to more than 600,000 per square kilometers by 2030 (World Bank, 2005).

Although urbanization stimulated economic development, it has caused wider gap between cities and among different social groups since cities in the developing countries have fewer resources to respond to such magnitude of change (UNFPA, 2007). Furthermore, urbanization process also caused significant increase of urban poor. Figure 1 indicates the percentage of people at different poverty level. This figure shows that more than $10 \%$ of the world population lived at USD 1 per day. Ironically, only about $20 \%$ of the world population lived above USD10.00 per day.

Despite significant growth of urban poor over the past few decades and the acute vulnerabilities, international aid still focuses on rural areas and largely ignores urban-based populations (Pantuliano et al., 2011). This is partially driven by a general assumption that those who live in the cities are better off. The reality has shown that the number of urban poor is increasing and not all urban dwellers has accessed to or benefited from the services and facilities offered by the city (Samat et al., 2010). The available data on Sudan showed that more than half of its urban dwellers are living under poverty line and this issue has affected $90 \%$ of its total population (Mahran, 2006). In Malaysia, for example, many strategies have been adopted to address poverty and to reduce its impact. Despite the numbers of poor people were reduced sharply, relative and urban poverty seems to be worsening, since the cost of living within the urban areas is much higher than that in rural areas (Samat et al., 2010). It is timely, therefore, to address urban poverty critically so that its underlying problem can be properly understood. This paper intends to fill in the gap; putting urban poverty in the political economy context that would reorient the research on poverty and allow for more studies to be undertaken. This might help planners as well as decision makers to adopt sound policies to alleviate poverty and reduce its consequences. Therefore, this paper focuses predominantly on the issue of urban poverty and its root causes in the developing countries taking Sudan and Malaysia as case studies.

\section{Conceptual Framework}

Urban poverty is defined by Sen (1999) quoted in UNESC (2007) as the deprivation of basic capabilities that provide a person with the freedom to choose the life he or she has reason to value. These capabilities include good health, education, social networks, control over economic resources, and influence on decision making that affects one's life. In Sudan, for example, the dimension of religion and hearing voices to politicians are also included in the definition of poverty. For the Ministry of Welfare and Social Security MWSS (2009) poverty is inability to meet the minimum basic necessities of life for individual and family that preserve or conserve religion, mind, money, and soul. The basic necessities include access to food, clothes, public transportation, house owned or ability to rent, potable water, health, education and security over money and life. Both definitions focus on the respect and dignity, access to income, and services as indictors of measuring poverty. In Malaysia, for example, poverty is defined based on poverty income line which is at RM510 approximately (170 USD) per month for a family of 4.6 households (Abdul Ghafor et al., 2007). This article accepted income or salary as important measurement for urban poverty because money allows a person to access food, housing, and services in towns, especially after the withdrawal of the state from provision of services and introduction of privatization.

In order to understand urban poverty, the conceptual framework adopted in this paper is given in Figure 2. This figure illustrates that the livelihood of local people is affected by the national policy as well as the international economic policies. Ineffective economic policies have put major constraints on the livelihood of both urban and rural communities. For example, change of the subsistence economy into cash crops or industrial related activities has weakened the adaptive mechanisms of rural people and limited their resistance to poverty (El Hadary, 2010). The collapse of rural economy has been aggravated by ecological degradation and natural hazards such as repeated droughts. As a consequence, large group of rural population are forced to flee into urban areas in searching of job opportunities. Influx of migrants to the cities has caused huge pressure on the limited urban services and infrastructure. As a result, unplanned urbanization has expanded rapidly in both terms spatially and demographically (Moral, 2011). This condition coupled with the lack of capital and human assets among the urban poor (rural migrant) have caused them to join informal sector and to make a living in a poor environment (German and Pyne, 2010).

\section{The Political Economy Approach}

Political economy focuses on the relationship between politics and economics. According to Todaro (1989) cited in El Hadary and Balla (2011) political economy concerns with emphasis on the role of power especially the bodies involve in economic decision making. This implies that those who are political empowered might use it to 
achieve some economic incentives at the expense of others (the weak). Due to the inequitable distributions of power between north and south, most of the developing countries have to accept the policies developed abroad which always lies behind the need and aspirations of the local people. This is a simply because people do best what they choose to do, rather than what World Bank or global market forces them to do. This has led some authors to describe the globalization of the economy as a new form of colonialism. The Director of the Third World Network in Malaysia notes that economically speaking; we are more dependent on the ex-colonial countries than we ever were. The World Bank and the IMF are playing the role that our ex-colonial masters used to play Danaher Kevin (1994) cited in (Buckley, 2004). For example, accepting loan from the World Bank has forced Sudan to modernize agriculture which has caused significant impact on the pastoral economy in many parts of Sudan, including the east (El Hadary and Balla, 2011). Therefore, rejecting the IMF loan as shall be seen later is considered as a key factor behind the secrets of economic success in Malaysia.

At the national level, inequitable distribution of power among different states benefitted powerful groups at the expense of others has created socio-economic inequality and led to regional disparities within the same state. For example, the discovery of oil in Sudan has benefited very few, the elite, and provided nothing than deep poverty to the majority (Pantuliano et al., 2011). In Philippine, the state uses "its" political power to circumvent certain regulations to facilitate the conversion of rice lands into industrial and urban residence (Philip, 1998). Following political economy approach, urban poor in developing countries is an outcome of structural processes related to ineffective economic policies rather than rural-urban interaction, high population growth or environmental degradation (Gomez and Jomo, 1997). The adoption of industrial policy by Malaysian government and changes of land use activities in Sudan due to the pressure or incentives from the "western developed nations" were held responsible behind the increasing number of urban poor. Therefore, in the perspective of this approach, urban poverty is an output of the policy and process of changing "rural lands" into urban uses that was made and facilitated by decision makers at international, national, and local levels.

\section{Political Economy and the International Policy-Structural Adjustment Programmes (SAPS)}

The previous discussion has shown that the livelihood of the majority of population in the developing countries has been affected heavily by the economic policies developed abroad rather than by ecological disaster. One of these policies is the Structural Adjustment Programme (SAP) which has been introduced by the World Bank and International Monetary Fund (IMF) on the eve of the oil crisis in the early eighties. Up to the year 1992, around 78 countries had to make economic adjustment based on this policy framework (Musa, 2000; Musa, 2002; Maharn, 2006; Dagdeviren, 2006). The central goals of structural adjustment were to open up countries for transnational corporations, shrink the size and role of government, rely on market forces to distribute resources and services, adoption of price liberalization, introduce privatization process, removal of government subsides, relaxation of foreign exchange controls, and tight control of credit (Stein, 1992, cited in Musa, 2000; Buckley, 2004). By integrating poor countries into the global economy, these countries have lost its autonomy and become passive in responding to the need of their local population. Thus, rejecting such policies as in case of Malaysia allows the country to implement its own policies that respond to the need of Malaysian communities rather than that imposed by IMF and international market. This paper argues that saying no to IMF policies and making financial market closed are the key success of the economic growth in Asian countries, mainly Malaysia and China. Therefore, it is no doubt that Malaysia which was severely affected by the financial crises in 1997, it has recovered at least as quickly as any country that implemented IMF policies, and gained a number of significant advantages by charting its own course out of the crisis (Buckly, 2004).

Like Malaysia, Sudan has rejected the IMF policy and embarked on its own Sudan's Structural Adjustment Programme (SSAP) in the early 1990s, but this suspension ended soon. After one decade, in August 2000 the government was successful in restoring the country's full membership in the IMF (Musa, 2002). Much has been said about SAP in escalating poverty and becoming a burden on national government in the developing countries (Anup Shah, 2010). In the case of Sudan, Maharn (2006) states that adoption of SAP has resulted in more scarcity, skyrocketing inflation rates, huge budget and balance of payments deficits, economic stagnation, and widespread poverty. In the same line, Babiker and Pantuliano (2006) states that SAP focused on economic growth without, on the most part, addressing how this growth is to be redistributed to the poor, especially the marginalized minorities such as the pastoralists. For Musa (2002), more than half of the population in Sudan lives under the poverty line and five million employees' ownership are destitute due to the adoption of SAP. This policy not only affected the vulnerable urban group who joined the informal sector but also the former government officials who, due to economic liberalization and increase cost of living, were pushed into poverty. As indicated by Musa (2000) the so-called structural adjustment and liberalization policies of the IMF and the 
World Bank had contributed the most to push an ever-growing number of working employee ownership below the poverty line in all regions of the world.

Privatization, which is adopted by most of the developing countries including Sudan in the early 1990s, is considered as the legal birth of SAP. Under the slogan of the excess labour, better efficient use of resources, and increase output production in term of quantity and quality, the government of Sudan has embarked on the privatization policy. Dagdeviren (2006) states that one hundred and seventeen state public enterprises have been privatized in Sudan, a little less than half of these were in the service and utility sectors, close to one third were in agriculture and a quarter in industries. No one can deny the role of privatization, if well managed, in creating competition, enhancing quality, and speeding up the improvement of the economic growth. However, in many developing countries, most of the economic policies are made to serve the wealthy and powerful people and always the government has been accused for offering economic chances to their loyalties and supporters (Anup Shah, 2011). Concessions such as investment opportunities, credit allocations exemption from custom duties, subsidies, financial support and the exclusive granting of licenses were some of the measures adopted by Sudanese government to empower their political supporters (El Amin, 2008). In this context, privatization has put some negative impact on labor market, increase urban poor and deprived a huge number of urban people from accessing income to pursue their livelihood. This was due to the lack of transparency, unsystematic, operating on trial and error approach, absence of accountability, unfair, chances given to political connections, absence of regulatory institutions, and no appropriate mechanisms for compensating workers (Dagdeviren, 2006). Although there is no real data on the total number of layoffs as a result of privatization, it seems that the outcome of such process in terms of employment was severe. According to Musa (2002) 5900 workers were believed to have been displaced following the liquidation of public agricultural corporations. Furthermore, according to Dagdeviren (2006) the total layoff was not more than thirteen thousand and in the manufacturing sector, the employment share of the public sector dropped from around 25 percent in the 1980 s to 10 percent in recent years.

This discussion illustrates the link between external policies and the escalation of urban poverty particularly in Sudan. Thousands of workers had been deprived from accessing job and had become vulnerable to urban poverty. The compensation given to the dismissed workers was beyond their expectation and in most cases lost its value since the process of acquiring it was slow. Moreover, no retraining was provided to compete and join the labor market to secure their livelihoods. Instead, the government introduces economic policies even harder and beyond the dream of the IMF and World Bank. This will be discussed in the next section.

\section{Political Economy and the National Policy}

Besides policy being formulated abroad, national economic policies also have to be blamed for the dramatic increase of the urban poor. Decline of agricultural sector as a consequence of national policy has led to the impoverishment of the majority of rural people in both countries. Oil has become the major driver of the economic growth and Sudan's total export revenues come from oil exports, which constituted $63 \%$ and $95 \%$ of GDP in 1998 and 2000 respectively (Medani, 2010). The sudden shift of the structure of Sudanese economy from purely agriculture to oil sector has led to degradation of the livelihood of the majority of farmers. In 2000 , the contribution of agriculture to GDP was almost $50 \%$ compared with $34 \%$ in 2009 . The contribution of services sector has been the fastest growing sector in recent years; it increased sharply from $30.9 \%$ in 2002 to $44.6 \%$ in 2009 (Central Bureau of Statistics CBS 2010). Besides its less contribution to the GDP, the decline in agriculture has caused negative impact on the food security in the country. Sudan which was once classified as the bread basket of the Arab World is highly dependent on imports of food (Mahran, 2006). Ironically, Sudan has gone from food surplus to deficit and astonishingly, in 2009 one third (35\%) of Sudan's imported items were things related to food (Central Bank of Sudan, 2009).

Oil was assumed to be able to enhance the development and generate better livelihood of the entire community. On the contrary, discovery of oil has hiked up the public expenditure of salary and running cost as compared with the development and benefit to the community. According to the Ministry of Finance and National Economy (2010), development received only $13.2 \%$ and $23.6 \%$ in the year 2000 and 2007 respectively while salary and running cost received $36.7 \%$ and $31.2 \%$ of the budget during the same periods. Moreover, the expenditure on the military has been exceptionally high and increased steadily over the years. The share of the military in the public budget increased from $11.5 \%$ in 1995 to $19.5 \%$ in 1997 and increased further to $28.8 \%$ for the year 2000 (El Amin, 2008). This rapid increase in non-productive expenditure has been achieved at the expense of social services as well as agricultural sector. 
Traditional agriculture, the main source of livelihood of the majority of the rural people is currently transformed into large-scale farming. Due to the fragile system of land tenure (customary law) huge land was taken from traditional producers and vested to investors, merchants and big companies (El Hadary, 2010). The total area under mechanized farming reached 17.2 million feddan (Note 1) compared with 2.0 million feddan in 1970, an increase of $606 \%$ (Egemi, 2006). Rural people lost their land and have not benefitted from such expansion. The majority of mechanized schemes holders in Sudan are considered as "outsiders" to the main mechanized farming areas, and most of them are traders or government employees without agricultural background (Ijaimi, 2006). Because their land was being converted to mechanized farming, most rural farmers migrated to urban areas in search of better economic opportunities (El Hadary, 2010).

Like Sudan, Malaysia has experienced economic growth due to rapid expansion of industrialization process. According to Rostam et al. (2010) the economy of Malaysia recorded a rapid growth rate at average between 6.0-9.5\% during 1970-1997 before it shrank during the Asian financial crisis in 1998-2005. The main driver of economic success was led by manufacturing sector in 1970. The export of manufactured goods increased sharply from about $12.0 \%$ in 1970 to $87.0 \%$ of total export in 1997. And its share to the GDP also rose from 13.3 to about $30.0 \%$ during the same period (UNDP 2005). Therefore, industrialization policy has created a lot of opportunities for people, and economically, Malaysia has become a country difficult to surpass. But the hegemony of this sector and its related activities has led to significant loss of agricultural land and green space, and becomes potential threat such as resource depletion or contamination of rivers from industrial discharge (Peterson, 1997; Sathiamurthy, 2008). Like Sudan, in Malaysia huge productive land was taken from rural communities to serve industrial and settlement purposes as well as to cater to the high demand of urban people (Ghazali, 2000; Abdullah and Nakagoshi, 2006). Consequently the contribution of agriculture to the total export has declined dramatically from $40 \%$ in 1980 to less than 8\% in 2003 (UNDP 2005). Many young people migrated to urban areas to work in the industrial sector. This has caused significant increase in the urban population of both Sudan and Malaysia.

\section{Urbanization and Urban Poverty in Sudan and Malaysia}

The earlier discussion showed that failed "developmental policy," coupled with conflict and natural disasters such as repeated drought as in case of Sudan constitute the major driving forces behind the widespread of unplanned urbanization and thus the increase in the number of poor people. Besides the war between south and north, Sudan in 2003 has experienced severe conflict in Darfur of the western region. The latter has led to an approximately 2.7 million people being internally displaced and an additional 2 million people affected by the conflict, making it one of the most widespread and protracted internal displacement contexts in the world (Seferis, 2010). Unlike Sudan, where collapse of rural economy coupled with conflict and natural hazards, were the key drivers behind rapid expansion of urban growth. Rapid growth of industrialization, regional disparities and concentration of services are some of the pulling factors behind the urbanization in Malaysia. Economic opportunity created by industrialization has attracted large number of people from within and outside Malaysia to migrate and live in the urban centres. It has been estimated that the average annual growth rates of urban population in the country were more than $4.9 \%$ during 1970-2000, compared with only about $2.3 \%$ for the country's population as a whole. In 2000 , more than $60 \%$ of Malaysia's population lived in urban areas (population above 10,000) (Rostam et al., 2010).

It is estimated that almost $40 \%$ of Sudan's total population is living in urban areas. According to CBS (2010) the total population in Sudan was around 42 million in 2009, 38\% out of this number was living in urban areas compared with only $8 \%$ on the eve of independence in 1956. Most of what has been considered as sub-urban or rural land in the past has been completely absorbed by the rapid encroachment of the cities. The creeping of urban into rural land has placed huge constraints on the infrastructure, agricultural production, housing demands, provision of social services and pushed the poor further into more marginal land. Currently in Sudan, seventy five urban centres have more than 20 thousands inhabitants and twenty out of these centres such as Khartoum are inhabited by more than one hundred thousand people, or may even be a million (El Hadary and Samat, 2011).

Sudan has experienced economic growth due to the discovery of oil and witnessed some political stability as a result of the signing of Comprehensive Peace Agreement CPA in 2005. However, the number of people under the poverty line is increasing and the country remains one of the poorest and unequal in terms of services of all African countries (El Amin, 2008). This was probably due to misallocation of resources away from the productive sectors of the economy to non-productive spendings such as war, security machine, and an enlarged bureaucracy) which had slowed down the economy and created limited employment opportunities. The discovery of oil has benefited few and surpassed the overwhelming majority of the Sudanese people. Wealth has become heavily concentrated in the hands of a few, especially in Khartoum, where the majority of the urban 
population has reaped little benefit (Pantuliano et al., 2011). As a consequence, more than $90 \%$ of the population in Sudan is classified as poor, and more than $50 \%$ of the poor is residing in urban areas (Mahran, 2006). According to Table 1 rural poverty in Sudan has increased from $64.2 \%$ in 1978 to $93.2 \%$ in 1992 while urban poverty has increased dramatically from $20.51 \%$ to $84.4 \%$ in 1978 and 1986 respectively and it reached $93.2 \%$ in 1992. The official documents published by the Ministry of Welfare and Social Security (MWSS) have shown that the proportion of the population below the poverty line in Northern Sudan is $46.5 \%$ compared with $64.9 \%$ in 2004, while in Southern Sudan it is anticipated to be $90 \%$ (MWSS, 2010).

The significant increase of urban poverty in Sudan has been escalated by the existence of huge IDPs who have been displaced by violence and created the conflict in the south and the west. It is estimated that, in 2009, the number of internally displaced persons was approximately 26 million, including 4.9 million in Sudan, 2.8 million in Iraq and 1.4 million in the Democratic Republic of the Congo (UNDP, 2009). Khartoum alone hosted around 2 million IDPs, most of whom were from the South (Eltayeb, 2003).

To address economic growth and eradicate poverty, Sudan has launched several strategic plans. This includes Fifteen-Year Plan (1977-82); the Comprehensive National Strategy (1992-2002); and the Sudan 25-Year Strategy (2007-2033), which is broken into five-year phases (2007-2011). The common objectives of these plans are to sustain economic growth, provide equal services, enhance rural development, reduce poverty through micro-finance schemes and promote good governance. Moreover in 2009, the state has increased the pro-poor spending from $6.2 \%$ to $10.2 \%$ of the GDP in 2009 (Ministry of Finance and National Economy, 2009). Despite all these efforts, poverty remains one of the serious problems in Sudan where almost half of the entire population is poor. This was probably due to the lack of political will and poor governance in tackling the challenges of urbanization and its consequences (Pantuliano et al., 2011).

Malaysia, on the other hand, has managed to bring down the incidence of poverty in the last thirty years. As shown in Table 2, the incidence of poverty in 1970 was $49.3 \%$ where urban poverty and rural poverty were $25.5 \%$ and $58.6 \%$ respectively. These figures were significantly reduced to $8.5 \%$ and $27.3 \%$ for urban and rural poverty respectively (EPU, 2009). This was probably due to strategies undertaken by the Malaysian government to introduce Five Year Malaysia Plans which started with The First Malaysian Plan (1966-1970). This plan started with huge allocation of money for education, health, and agriculture irrigation project (Malaysia, 1970).

However, economic disparity among major ethnic groups (Malays, Chinese, and Indians) was quite large. Racial stress led to outbreak of social disharmony where racial riot of 1969 occurred. This was probably due to problem of ethnic specialization in geographical setting and certain professions, with the Chinese were tin miners dominating the marketplace in urban and rural areas, the Malays were farmers in the rural areas or dominated the civil service, and the Indians were rubber estate workers in rural areas and participating in specialist professions such as law or medicine (Malaysia, 1970). To address these disparities and achieve economic growth with equity, Malaysia has gone into series of strategic plans. These plans include New Economic Policy (1971-1990), National Development policy (1991-2000), National Vision Policy (2001-2005), Ninth Malaysia Plan (2006-2010) and Vision 2020. The NEP (1971-1991) concentrated on building a country with an advanced economy, balancing social development and reducing income disparity among different ethnic groups. The government offered incentives to industrialize the Malaysian economy by promoting Malay entrepreneurship and upgrading Malay management skills for manufacturing ventures with the hope that Malays would have 30\% of asset acquisition in Malaysia (Malaysia, 1970). By so doing Malaysia has succeeded in reducing poverty to less than $25 \%$ (UNDP, 2005). This has been achieved through raising of income levels, increasing employment opportunities among all Malaysians irrespective of race, and a strong emphasis placed on agricultural and rural development, labour-intensive export industrialization, and public investment into education, health, and infrastructure. Later on Malaysia delivered the Ninth Plan (2006-2010), the overall objective was to achieve greater success to build a civilization that would elevate the nation's dignity. The five pillars of this plan are as follows: first to move the economy through generation of new knowledge-intensive activities and employment in ICT, biotechnology, and services. The second pillar is to raise the country's human capital (human resource development) by providing high quality output of education from pre-school up to higher education. The third is to address persistent socioeconomic inequalities, eradicating poverty, generating more balanced growth and ensuring that the benefits of growth are enjoyed by the Malaysian people in a fair and just manner. The fourth is to improve the standard and sustainability of quality of life. The Government will continue to provide for basic needs such as water, energy, housing, transportation and other amenities. The final pillar is to strengthen the institutional and implementation capacity of the country. The Government will also address issues related to corruption and integrity in the public sector, the private sector and among the general public. 
Malaysia Plans have succeeded in fostering economic growth in the country and poverty was significantly reduced to $6.1 \%$ in 1997 with $2.1 \%$ and $10.9 \%$ urban and rural poverty respectively. In 2007 , for example, poverty in Malaysia was $3.6 \%$ with $2.0 \%$ for urban poverty and $7.1 \%$ rural poverty. During the Ninth Malaysia Plan, various initiatives were undertaken to envisage Malaysia's GDP to grow (in real terms) by $6.0 \%$ per annum over the 2006 to 2010 period. This included moving the economy up the value chain, to raise the capacity for knowledge, to address socio-economic inequalities and to strengthen and sustain quality of life (EPU, 2006).

This ever impressive experience has led Malaysia to move further in the socio-economic and human index. Table 3 reflects some facts about the socio-economic characteristics and Human Development Index (HDI) of Sudan and Malaysia produced by (UNDP, 2007). Accordingly, all countries included in the HDI are classified into one of four clusters of achievement in human development: very high human development (with an HDI of 0.900 or above), high human development (with an HDI of 0.800 or above), medium human development (HDI of 0.500-0.799) and low human development (HDI of less than 0.500). Unlike Sudan, Malaysia has achieved some progress as it ranked 25 in the Poverty Development Index compared with 104 for Sudan (see Table 3 for more details).

Moving from zero to one in the HDI measurement means a country has shown high level of human development. It is important to note that Sudan's HDI has improved by $1.12 \%$ annually, from 0.491 to 0.531 over the period 2000 and 2007 respectively. The Sudan HDI of 0.531 ranked 150, places it at the bottom of the medium cluster countries, after Haiti and above Ghana. This puts great difficulties on the country to meet the MDGs objectives by 2015. Based on HDI measurement, Malaysia is currently on the right track to fulfill the needs of MDGs by 2015. The HDI increased by $0.81 \%$ annually from 0.6 in 1980 to 0.8 in 2007 and almost approaching one (0.829) and ranked 66, places it at the high development cluster countries.

\section{Policy of Poverty Eradication and Lessons Learned}

As indicated in this paper, half of urban population in Sudan has been pushed into poverty due to inefficient policies developed at local and international levels. Several attempts have been made by national government and civil societies to eradicate poverty. These include among others solidarity fund Takaful, social insurance fund, the students support fund, the national retirement fund, health insurance fund, and Islam social support funds Zakat. To maintain social balance, the government also increased salaries among civil servants, provided micro-finance credit, and introduced low or affordable housing programme. The overwhelming objective of all these supports was to mitigate and alleviate urban poverty (Abdul Ghafor et al., 2007).

Despite all these efforts, the number of urban poor is mounting. Several issues need to be highlighted to properly address the poverty issue among urban dwellers in Sudan as well as in other developing countries. First, a comprehensive and reliable data on poverty, collected at household level, would be useful to calculate the actual number of urban poor and properly devise the suitable programme in alleviating poverty. In Penang State, Malaysia and in Rajshahi City Bangladesh, for example, household survey was conducted and the location of poor household was mapped using Geographic Information System (GIS) in order to see spatial distribution of the poor and evaluate the accessibility of these household to urban services (Samat et al., 2010; Moral, 2011). Such approach allows policy makers to properly distribute the aid and plan for appropriate programme to empower the poor community. Second, the indicator used to measure poverty is still debatable. In addition to Poverty Income Line, other forms of deprivation should also be considered. For example, poor accessible to health and education among the poor may significantly affect the livelihood of these people (Samat et al., 2010). Third, the problem of mismanagement and corruption may occur due to the tedious and time consuming procedure of distributing fund. Poor people also have to show collateral especially when trying to acquire small loan from the bank. Although money allocated for pro-poor spending is less, not all of it accessed by the poor. In the year 2008 only $3 \%$ of the microfinance credit went to the poor, the rest might have been used for investing channel (Mahran, 2006). Fourth, lack of coordination between all stakeholders involve in mitigating poverty. Each institution works separately in allocating funds or resources which sometimes caused duplication of duties or caused the same household to receive aid from more than two agencies. Thus creating Poverty Information System (PIS) and national geo-database will benefit all and overcome most of the problems mentioned. Finally, the political will or state commitment has to be strong and eradicating poverty must be one of the government's top agendas.

In September 2000, Sudan and Malaysia together with other 188 countries have signed the Millennium Declaration where reduction of poverty by half in 2015 is one of its eight Millennium Development Goals. Our data has shown that poverty in Sudan has declined by $20 \%$, from $64 \%$ in 2005 to $46 \%$ in 2009; still, achieving MDG could be a challenge given the fact that half of its population is now living under poverty line. Thus it is difficult, if not impossible for Sudan to achieve the MDG goal, especially in a situation where the country ranked 
as second from the last in corruption measurement (Organization of Transparency, 2009) and scored 20.5 in hunger index. According to the Global Hunger Index (2008) Sudan received a score of 20.5, which is considered as "alarming" compared with Malaysia which scored only 6.5 (International Food Policy Research Institute IFPRI, 2008). In this line Ali (2004) states that Sudan needs at least 28 years to achieve the goal on condition that its GDP growth rate constitute at about 7 percent per annum. Not far from Ali, Medani (2008) states that Sudan's efforts to reduce diseases like malaria and tuberculosis are still far from achieving the target goals, and more resources and efforts are needed if they are to be eradicated by 2015. This paper added that the rate of poverty in Sudan will increase especially after the separation of the South in July 2011. This because most of the oil fields are now located in the southern Sudan. Thus lost of oil due to the separation of the South means the collapse and ruin the whole economy, if no serious action is taken to compensate such a great loss.

Unlike Sudan, Malaysia has eliminated the incidence of poverty very sharply and even went beyond the MDG expectation. Malaysia managed to reduce poverty from almost 50\% in 1970 to $22.8 \% 1990$ and to only $5.7 \%$ in 2009. Her ambition is to reduce it to zero in the Vision 2020. Despite this positive progress in eradicating poverty, incidences of poverty can still be found and it varies considerably by state and among the various ethnic groups. According to UNDP (2005) the highest incidences of poverty are in Sabah 16\% and Kelantan 12\% while ethnic differences remain marked with $7.3 \%$ among Malays, $1.5 \%$ for Chinese, and $1.9 \%$ for Indians.

Sudan and Malaysia has shared some common similarities, despite that each has adopted its own approach in addressing urban poverty. Both countries have experienced economic growth in a multi ethnic and culturally diverse community. In addition, both of these countries inherited the legacy of British administration and reached their independence almost at the same time (Sudan, 1956; Malaysia, 1957). In the early 1970s, more than half of their populations were living under poverty line. Despite the effort made in achieving the MDG, Sudan is still lacking behind and has a long road to go compared with Malaysia. It seems that, especially for Sudan, poverty reduction does not lie within the top priorities of the current regime, as the government's high expenditure is still for defense and security rather than development and services. Unlike Sudan, Malaysia has initiated its own policy targeting economic growth not as an end in itself but as an engine for socio-economic development. Several points have been highlighted to uncover the secrets of Malaysian success in eradicating poverty, addressing socio-spatial inequality and at the same time sustaining its economic growth. This paper aims to propose Malaysian model as a guide to be implemented in a country like Sudan and other developing nations. The main points of success include, but not limited to, the availability of rational and strong economic policy makers, formulation of home-grown economic policy, responding to the local needs rather than international market, political will and ethics commitment, refused policy cooked out side if not within the line of the country's need, and most important point is the ability to implement policies. In summary "good governance" and overestimating the incidence of poverty rather than underestimating it has contributed much to the success. These points explain why Malaysia has in a very short time achieved economic growth with equity in a multiethnic, multireligion and culturally diverse community.

\section{Conclusion}

This paper highlights the ineffective national and international economic policy such as SAPs that has led to accelerate urban poverty in Sudan and Malaysia. As a consequence of failed developmental policies, urban growth has expanded dramatically and the number urban people have skyrocketed from $8 \%$ to $40 \%$ in Sudan and to more than $60 \%$ of Malaysia. The vulnerable migrants have been welcomed badly and in most cases not benefiting from what the city provides to urban dwellers in term of services and income. Despites the efforts made to eradicate urban poverty; still the number of urban poor is mounting, particularly in the case of Sudan. Significant differences exist between the two experiences in addressing poverty and socio-economic inequality. Unlike Sudan, Malaysia has moved further in achieving MDGs and the number of urban poor has declined very sharply. Our findings have shown that, formulated home-grown policies that respond to the need of local people rather than that of the international market and the ability to implement policies are the main drivers behind the secret success of the Malaysian model.

\section{Acknowledgement}

Authors wish to thank Universiti Sains Malaysia for funding this research under Research University Grant and for funding Dr Yasin Abdalla ElTayeb ElHadary under USM Fellowship Scheme. Authors also would like to thank Institute of Postgraduate Studies IPS, Universiti Sains Malaysia USM for proof reading the article.

\section{References}

AbdulGhafor, S., Hatta, Z. A., Sulaiman, J., et al. (2007). Kajian Sosioekonomi Bumiputera Pulau Pinang. Pinang-Malaysia: Unit Perancang Ekonomi Pulau Pinang. 
Abdullah aiful Arif, \& Nakagoshi Nobukazu. (2006). Changes in landscape spatial pattern in the highly developing state of Selangor, peninsular Malaysia. Landscape and Urban Planning, 77, $263-275$. http://dx.doi.org/10.1016/j.landurbplan.2005.03.003

Ali, A. (1994). Structural Adjustment Programmes and Poverty in Sudan. Paper presented at the Arab Research Centre.

Babiker, M., \& Pantuliano, S. (2006). Addressing chronic livelihoods vulnerability in Red Sea State. Red Sea Sudan: Oxfam.

Buckley, R., \& Fitzgerald, S. (2004). An Assessment of Malaysia's Response to the IMF during the Asian Economic Crisis. Singapore journal of legal studies, July, 96-116.

Central Bank of Sudan. (2009). Annual Report 2009. Khartoum.

Central Beruau of Statistics Sudan. (2010). Retrieved 15 October, 2010, from http://www.cbs.gov.sd/

Choguill, C. L. (1994). Crisis, chaos, crunch? planning for urban growth in the developing world. Urban Studies, 31(6), 935-945. http://dx.doi.org/10.1080/00420989420080761

Dagdeviren, H. (2006). Revisiting privatization in the context of poverty alleviation: the case of Sudan journal of international development, 18, 469-488.

Danaher, K. (Ed.). (1994). 50 Years is enough: the case against the World Bank and the International Monetary Fund.

Department of Statistics Malaysia. (2000). Population and housing census of Malaysia 2000.

Department of Statistics Malaysia. (2008). Population, Household \& Living Quarters.

Department of Statistics, M. (1991). Population and housing census of Malaysia 1991.

Devas, N., \& C., R. (1993). The urban challenge. In N. Devas \& C. Rakodi (Eds.), Managing Fast Growing Cities: New Approaches to Urban Planning and Management in the Developing World: Longman Scientific \& Technical.

Egemi, O. (2006). land tenure in Sudan challenges to livelihood security and social peace. In G. E. El Tayeb (Ed.), land issue and peace in Sudan. Khartoum-Sudan: Sudan Environment Conservation Society.

El Amin, K. A. (2008). Poverty causes in Sudan: some economic and political aspects 1990-2000. In Economic Research Forum.

El Hadary, Y. A. (2010). Challenges facing land tenure system in relation to pastoral livelihood security in Gedarif State, Eastern Sudan. Geography and Regional Planning, 3(9), 208-218. http://www.academicjournals.org/jgrp/PDF/pdf2010/Sep/Elhadary.pdf

El Hadary, Y., \& Balla, A. (2011). Challenges facing pastoral communities in the eastern Sudan. Germany: Lambert Academic Publishing. ISBN 10: 3844307478 / 3-8443-0747-8

El Hadary, Y., \& Samat, N. (2011). Political Economy and Urban Poverty in the Developing Countries: Lessons learned from the Sudanese experience. Journal of Geography and Geology, 3(1), 63-76. http://dx.doi.org/10.5539/jgg.v3n1p63

El Tayeb, G. E. (2003). Understanding slums: The case of Khartoum, Sudan. London Earthscan: UN-Habitat.

EPU - Economic Planning Unit. (2006). Malaysian Quality of Life, Putrajaya. Retrieved 10 November, 2010, from http://www.epu.gov.my/248

EPU - Economic Planning Unit. (2009). Knowledge Content in Key Economic Sectors in Malaysia Phase II. Retrieved 10 November, 2010, from http://www.epu.gov.my/248

German, E., \& Pyne, S. (2010). Dhaka: the fastest growing megacity in the world, Global Post, Sept 8, 2010. $\begin{array}{llll}\text { Retrieved } & 29 & \text { September, } & \text { from }\end{array}$ http://www.globalpost.com/dispatch/asia/100831/bangladesh-megacity-part-one

Ghazali, S. (2000). Managing Land for Housing: A study in Peri-Urban Villages in Penang, Malaysia. Malaysian Journal of Tropical Geography, 31(1 and 2).

Gomez, E. T., \& K. S. J. (1997). Malaysia's Political Economy: Politics, Patronage and Profits Cambridge: Cambridge University Press. 
Ijami, A. (2006). Mechanized farming and conflict in Sudan. In G. E. El Tayeb (Ed.), land issue and peace in Sudan. Khartoum-Sudan: Sudan Environment Conservation Society.

International food policy research institute Global hunger index IFPRI. (2008). The Challenge of Hunger.

Mahran, H. (2006). Public policy and poverty reduction in Sudan, 1971-2002. Paper presented at the Public Policy and Poverty Reduction in the Arab Region.

Malaysia. (1970). Five Year Malaysia Plan which started with The First Malaysian Plan (1966-1970).

Malaysia. (2006). Ningth Malaysia Plan 2006-2010.

Medani, M. A. (2008). Can the Sudan Achieve the MDGs Given its past and present Expenditures Allocation Pattern? Bergin: CMI

Medani, M. A. (2010). Budgetary allocations and resource distribution to different tiers of government. Paper presented at the Global Financial Crisis Discussion Series Paper 19: Sudan Phase 21

Ministry of finance and National Economy. (2010). Retrieved from http://www.mof.gov.sd.

Ministry of Welfare and Social Security Report. (2009). Ministry of Welfare and Social Security Report. Retrieved 10 October, 2010, from http://www.wagescouncil.gov.sd

Moral, M. J. B. (2011). Locating the Poor: Spatial Poverty Mapping of Households in Rajshahi City. Universiti Sains Malaysia, Penang.

Musa, E. A. (2000). Sudan Structural Adjustment Programme (Ssap): Some Implications for Laboring the Formal Sector. African Administrative Studies, 56.

Musa, E. A. (2002). The Impact of Public Enterprise Reforms on the State Budget in Sudan. Paper presented at the Administration for Development Tangier Morocco.

Organization of Transparency. (2009). Corruption Perceptions Index 2009 Regional Highlights: Sub-Saharan Africa.

Pantuliano, S., Buchanan-Smith, M., Metcalfe, V., et al. (2011). City limits: urbanisation and vulnerability in Sudan. United Kindom: UKaid International Developmet. http://www.odi.org.uk/resources/download/5290.pdf

Philip, F. K. (1998). The politics of urban-rural relations: land use conversion in the Philippines. Environmental and Urbanization, 10(1). http://dx.doi.org/110.1177/095624789801000116

Rostam Katiman, Jali, M. F. M., \& Toriman, M. E. (2010). Impacts of Globalisation on Economic Change and Metropolitan Growth in Malaysia: Some Regional Implications. The social sciences, 5(4), 293-301. http://dx.doi.org/10.3923/sscience.2010.293.301

Samat, N. (2002). A geographic information system and cellular automata spatial model of urban growth for Penang State, Malaysia. University of Leeds, Leeds UK.

Samat, N., Fatimah Hijles Mahdi, Aslinda Osman, et al. (2010). Application of geographic information system in identifying deprived areas. Paper presented at the 7th international Malaysian studies conference.

Seferis, L. (2010). Darfur's Displacement Dilemma: Operational Coordination and Aid Reform for IDP Returns. PRAXIS The Fletcher Journal of Human Security, XXV.

The Republic of Sudan National Population Council General Secretariat (NPC/GS). (2010). Sudan Millennium Development Goals Progress Report Khartoum.

UNCHS - United Nations Centre for Human Settlements. (1996). An Urbanizing World: Global Report On Human Settlements. UK: Oxford University Press.

UNDP. (2005). Malaysia achevining mellenuim development Goals: challenges and successes. Kuala Lumpur, Malaysia.

UNDP. (2006). Macroeconomic Policies For Poverty Reduction: The Case Of Sudan Khartoum Sudan.

UNDP. (2009). Human Development Report, Overcoming barriers: Human mobility and development.

UNESC. (2007). Facing the Challenges of Urbanization and Urban Poverty in Asia and the Pacific in Urban poverty and the Working Poor. Bangkok Thiland.

United Nation Population Fund-UNFPA. (2007). Linking Population, Poverty and Development, Urbanization: A Majority in Cities. Retrieved 28 September, 2010, from http://www.unfpa.org.pds/urbanization.htm

Wages Council. (2009). Ministry of Welfare and Social Security Report. Retrieved 10 October, 2010, from http://www.wagescouncil.gov.sd 
Wages Council. (2010). Ministry of Welfare and Social Security Report. Retrieved 10 October, 2010, from http://www.wagescouncil.gov.sd

World Bank. (2005). The Dynamics of Global Urban: Expansion Transport and Urban Development. Washington D.C.

\section{Notes}

Note 1: Feddan is 1.04 Acres or 0.42 Hectares

Table 1. Percentage of poverty in rural and urban area in Sudan (1968-1992)

\begin{tabular}{|l|l|l|l|l|}
\hline Type & 1968 & 1978 & 1986 & 1992 \\
\hline Urban & 15.9 & 20.5 & 52.9 & 84.4 \\
\hline Rural & 62.9 & 64.2 & 83.1 & 93.2 \\
\hline The total & & 54.3 & 77.8 & \\
\hline
\end{tabular}

Source: Ali (1994) cited in Mahran (2006).

Table 2. Percentage of poverty in rural and urban area in Malaysia (1970-2007)

\begin{tabular}{|l|l|l|l|l|l|l|l|l|l|l|}
\hline Type & 1970 & 1979 & 1984 & 1989 & 1992 & 1995 & 1997 & 1999 & 2004 & 2007 \\
\hline Urban & 25.5 & 17.5 & 8.5 & 7.1 & 4.7 & 3.6 & 2.1 & 3.3 & 2.5 & 2.0 \\
\hline Rural & 58.6 & 45.8 & 27.3 & 21.1 & 21.2 & 14.9 & 10.9 & 14.8 & 11.9 & 7.1 \\
\hline Malaysia & 49.3 & 37.4 & 20.7 & 16.5 & 12.4 & 8.7 & 6.1 & 8.5 & 5.7 & 3.6 \\
\hline
\end{tabular}

Source: Department of Statistics, Malaysia (2008).

Table 3. Selected indicators of human poverty for Sudan and Malaysia in the year 2007

\begin{tabular}{|l|l|l|l|l|}
\hline \multirow{2}{*}{ Issue } & \multicolumn{2}{l}{ Sudan } & \multicolumn{2}{l|}{ Malaysia } \\
\cline { 2 - 5 } & Rank & degree & Rank & Degree \\
\hline HDI value & 150 & 0.531 & 66 & 0.829 \\
\hline Life expectancy at birth & 142 & 57.9 & 55 & 74.1 \\
\hline GDP per capita (PPP USD) & 137 & 2086 & 61 & 13518 \\
\hline Immigrant destination - \% Total population & 128 & 1.7 & 58 & 7.9 \\
\hline Adult literacy rate (\% ages 15 and above) & 126 & 60.9 & 62 & 91.9 \\
\hline Human poverty index & 104 & 34 & 25 & 6.1 \\
\hline Probability not surviving Age 40 \% & 123 & 23.9 & 29 & 3.7 \\
\hline Adult illiteracy rate (\%ages 15 and above) & 126 & 39.1 & 62 & 8.1 \\
\hline People not using improved water source (\%) & 113 & 30 & 22 & 1 \\
\hline Children underweight for age (\% aged under 5) & 132 & 41 & 53 & 8 \\
\hline Emigration rate (\%) & 149 & 1.7 & 126 & 3.1 \\
\hline
\end{tabular}

Source: Human Development Report 2009 - HDI rankings. 


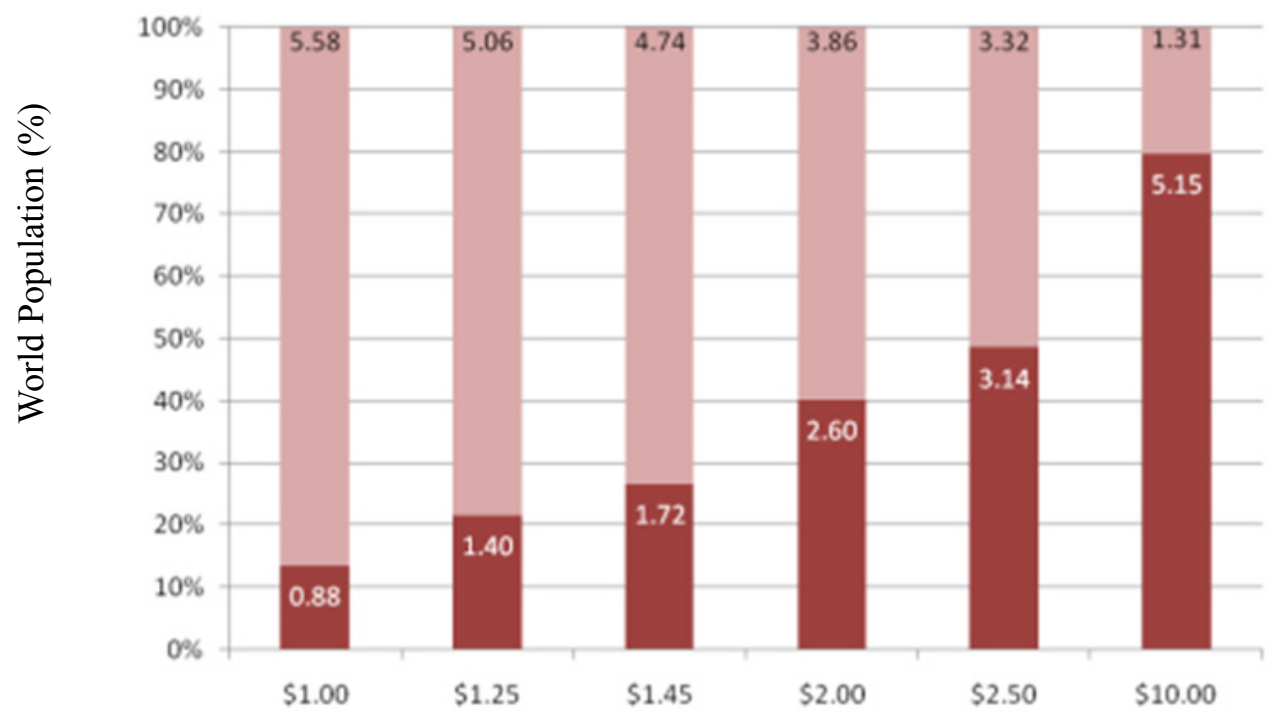

Poverty Line (USD Dollars a day at 2005 Purchasing Power Parity)

Numbers inside bars are world population at that indicator, in billions

Below the poverty line

Above the poverty line

Figure 1. Percentage of people in the world at different poverty levels (Source: World Bank Development Indicator (2008) as cited from Global Issues (2011) accessed from http://www.globalissues.org/article/26/poverty-facts-and-stats (April 20, 2011)

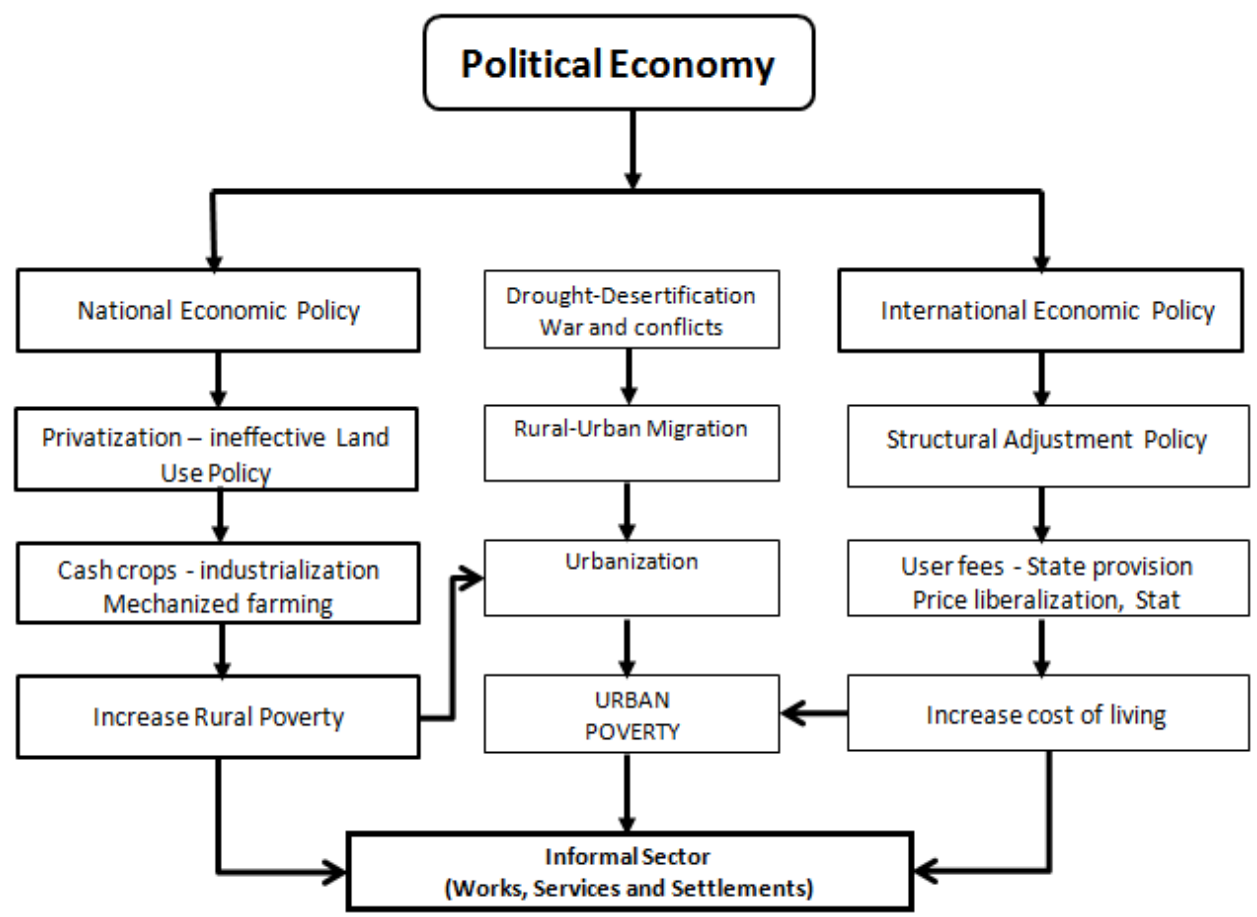

Figure 2. The schematic illustration of urban poverty (Source: El Hadary and Samat, 2011) 